\title{
Digital Mental Health and COVID-19: Using Technology Today to Accelerate the Curve on Access and Quality Tomorrow
}

\author{
John Torous $^{1}$, MD, MBI; Keris Jän Myrick ${ }^{2}$, MS, MBA; Natali Rauseo-Ricupero ${ }^{1}$, LCSW; Joseph Firth ${ }^{3}$, PhD
}

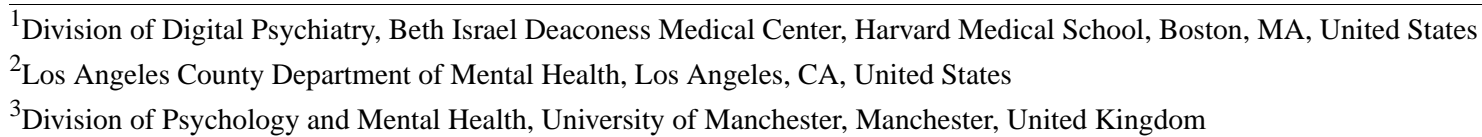

\section{Corresponding Author:}

John Torous, MD, MBI

Division of Digital Psychiatry

Beth Israel Deaconess Medical Center

Harvard Medical School

Rabb 2, 330 Brookline Ave

Boston, MA, 02215

United States

Phone: 161766700

Email: jtorous@bidmc.harvard.edu

\section{Related Articles:}

Comment in: https://mental.jmir.org/2020/4/e19547/

Comment in: https://mental.jmir.org/2020/8/e23023/

\section{Abstract}

As interest in and use of telehealth during the COVID-19 global pandemic increase, the potential of digital health to increase access and quality of mental health is becoming clear. Although the world today must "flatten the curve" of spread of the virus, we argue that now is the time to "accelerate and bend the curve" on digital health. Increased investments in digital health today will yield unprecedented access to high-quality mental health care. Focusing on personal experiences and projects from our diverse authorship team, we share selected examples of digital health innovations while acknowledging that no single piece can discuss all the impressive global efforts past and present. Exploring the success of telehealth during the present crisis and how technologies like apps can soon play a larger role, we discuss the need for workforce training, high-quality evidence, and digital equity among other factors critical for bending the curve further.

(JMIR Ment Health 2020;7(3):e18848) doi: $\underline{10.2196 / 18848}$

\section{KEYWORDS}

digital health; emergency response; telehealth; apps

The COVID-19 crisis and global pandemic has highlighted the role of telehealth and digital tools like apps to offer care in times of need. Many clinicians and patients alike are now realizing the full potential of these digital tools, as they are forced to, for the first time, utilize them to connect in a time when in-person and face-to-face visits are impossible. Harnessing this surge in interest, enthusiasm, and acceptance has immediately been recognized as an opportunity for the field [1]. Thus, the field's next steps will also be critical in ensuring digital health is used today to deliver the best care during the current crisis, ready for any resulting mental health spike following the immediate crisis, and prepared to support future crises as well as care as usual. In this perspective piece, we draw largely from our team's experience with digital health and recognize the impressive global innovation and research in this space that cannot be captured in any single piece [2-9].

Telehealth is the right solution to deliver mental health care in today's crisis. The only established contraindication to telehealth is a patient not wishing to partake. The temporary waiving of numerous rules and regulations around telehealth by the US government on March 17, 2020, was unprecedented [10]. It was made possible because of the strong and clear evidence base for the efficacy of telehealth and decades of high-quality research [11]. Our Boston team is already using telehealth to see patients during this current crisis, and feedback from patients as well as colleagues who are just starting to use telehealth suggests that this may be the new normal for many. 
Digital therapy programs that can offer courses of evidence-based therapies also have a role in the crisis, given their unique potential for scalability. However, issues of real-world engagement with these programs [12] and high risk of bias in many studies [13] warrant caution in ensuring that plans for encouraging and maintaining meaningful engagement are in place before purchasing these programs or services. Workflow integration issues are also critical to consider when beginning to utilize these types of programs in care settings, and lack of attention here can lead to low uptake and support by both patients and staff $[14,15]$. New innovations in augmented and virtual reality systems hold great promise [16], but are not yet easily scalable or accessible to all for use in this current crisis.

Tools like apps also have an important role, given their availability and scalability, but with similar caveats. Current evidence for apps for behavior change remains limited [17], and self-help for mental health remains equally limited [18]. Although companies will boast about positive outcomes from randomized controlled trials [19], results from higher-quality studies with valid comparisons groups, proper statistical analysis, and low risk of bias do not tell the same story $[18,20]$. This is not to say that mobile technologies do not have a role in care. Rather, they possess a tremendous and still largely untapped potential to augment and extend care. Our team in Boston uses mobile apps to better understand the unique lived experience of each patient [21] in both our research as well as our digital clinic. Using apps in conjunction with current care has been shown to greatly increase the efficacy of app interventions [18]; in addition, the sensor, survey, and digital phenotyping data can be used to make more informed, data-driven, and evidence-based decisions about care. Our (JT and NRR) experiences of running a novel "digital clinic" in Boston offering such hybrid care confirm the theoretical advantages with real-world benefits. Now, bringing app data into telehealth visits offers a practical means for patients to share data of their lived experience during this crisis (eg, changing exercise and stress levels or response to new medications) and practice new therapy skills between sessions.

In our experience, the most effective apps are the ones that can be customized to each patient and fit with their personal care goals and needs as well as apps for peer support. Our team is fortunate in that we have created our own app tool (freely available and open source) [22] that we often utilize in research and care, but we realize that different apps are often needed for different situations. Picking from those different apps is challenging as many offer little protection of user data, make exaggerated claims, may be ineffective, and often are quickly abandoned because of usability issues [18,23,24]. Thus, careful attention is warranted when recommending such apps to patients [25]. Thus, relying on static lists of "top apps" or others" scoring systems for selecting apps is often unhelpful and even dangerous, given how out of date these recommendations are [26]. Although many app-evaluation tools exist, our research and development of the American Psychiatric Association's app evaluation framework offers a practical and ready-to-use resource today for both patients and clinicians [27].

One underdeveloped area for digital therapy and mental health apps is the remote delivery of "lifestyle interventions." There is now increasing evidence that lifestyle factors such as physical exercise, sleep, and healthy diet play an important role in self-management of mental health conditions [28]. Consideration of these lifestyle factors for mental health may be particularly important during periods of isolation/prolonged home time, due to the adverse psychological effects of reduced exercise [29] or prolonged sedentary behavior [30], and the ongoing debate about certain types of screen time and social media usage (with quality of online interactions mattering more than time) [31]. Social distancing (which is actually physical space distancing) and self-quarantine will place millions of people at higher risk of disruption to lifestyles that likely benefited their mental health. Nonetheless, digital technologies and smartphone apps may also present a novel platform for the remote delivery of lifestyle interventions [32]. However, there is still a great need for further research to establish how this can be done in an engaging and effective way, to reach those with mental illness.

Looking beyond the immediate consequences of infection with the virus and the mental health impact of self-quarantine and social distancing, a second mental health crisis looms. In times of economic recession, there is often high prevalence of mental health disorders, misuse of substances (or substance use disorder), and deaths from suicide [33]. The need for more mental health services will tax an already overburdened health care system, and digital solutions will be called upon again. Learning from decades of prior research and experience, hybrid solutions that offer a blend of face-to-face and online or app-based treatment will be the most effective solution [14,18].

Ensuring the field advances from the recent interest and use in digital health to further accelerate access and quality of care beyond these immediate and imminent crises is the next challenge. The efforts reducing implementation barriers to video visits (also known as synchronous telehealth) during this current crisis highlight the potential to bend the curve on access to care (Figure 1). Further efforts and investments will be required to now have more access and quality as the field aims to fully utilize technologies like apps and beyond. Investing in the evidence, outcomes, workforce, engagement, and ethical uses of these newer technologies and innovations will allow them to bend the curve and truly deliver on their full potential, just as we are seeing telehealth today benefiting from its legacy of prior investments. 
Figure 1. Bending the curve further on access and quality of care will require increased efforts around safety, evidence, engagement, outcomes, and implementation. However, these increased efforts will yield greater returns at each step. The COVID-19 crisis has (at least temporarily) removed implementation barriers to synchronous telehealth through regulatory changes, and the evidence, safety, and engagement were already in place before. The next steps to use apps toward asynchronous telehealth will require continued effort but yield even greater increases in access to high-quality care.

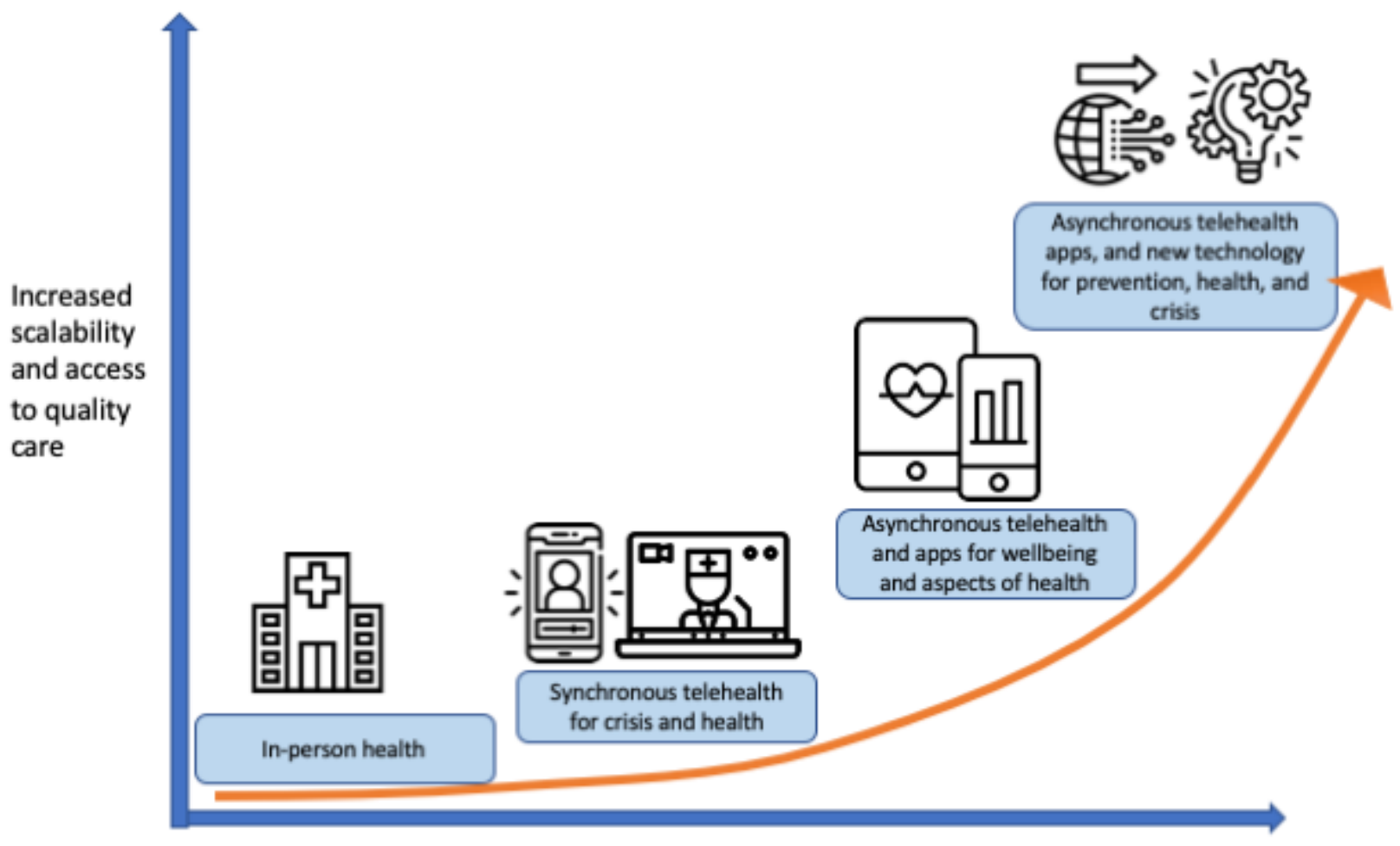

Increased efforts required around safety, evidence, engagement, outcomes, and implementation

Among some of these new efforts required, a critical one is teaching medical professionals, trainees, and peer support specialists how to use digital and mobile technologies for delivering care. Frameworks for competencies already exist [34,35], and a few have already been implemented. Our personal experience in teaching psychiatry residents about mobile mental health in formal didactics has been positive, and there are already many examples of teaching telehealth [36,37]. Training new care team members around digital health, a role we have termed a digital navigator [38], offers opportunities to easily liaison between digital and classical care. Although training does not offer an immediate solution to the current crisis, it creates the workforce and builds the capacity to support increased access to care for the mental health sequelae of the current crisis and readiness for the next.

Training new providers is, however, only half the picture. Ensuring all patients, especially the most vulnerable ones, have the digital literacy and competency to partake in digital care is a matter of equity and social justice. Many people today find it easy to use their smartphone to set reminders, download apps, join video calls, and connect with peers. However, many people do not, and offering training and skills building is critical to ensure digital health actually offers help to those who need it the most [39]. Our Digital Opportunities for Outcomes in Recovery Services (DOORS) program offers 6-8 weeks of group sessions to develop smartphone skills and competences that have been well received by those with serious mental illness [38] and is freely shareable for others to expand upon. Focusing on and developing programs like this one, which ensures everyone is able to connect and receive care, may not have the attention-grabbing status like artificial intelligence and virtual reality, but such programs are likely of more importance now more than ever.

We must also be aware of the disparities that impact people with low income, those receiving public benefits, and cultural and linguistically diverse communities that may not have access to even basic technology including digital mobile technology. Subsidized phone programs such as Lifeline Assistance may have data, speed, and calling limits. As such, the people we serve may have to make choices about what they will download and how they will use their mobile devices, even though greater opportunities exist. Further, we need to understand how people use their mobile devices-from sharing them with family, housemates, and friends to "renting them for a day" to access funds to meet basic needs - as this will impact privacy as well as research if we are not sure whose hands the phone really is in. During this time of self-quarantine and stay-at-home orders, if one is homeless or unstably housed, charging the phone or laptop is a huge barrier as is finding public or library hotspots. For now, and in the future, we need to prepare the workforce to conduct street psychiatry and outreach work in order to carry chargers and portable hotspots and provide treatment via street psychiatry or connecting with peers or outreach workers. Some people still have and use flip phones (non-smartphones), and this population cannot be ignored. For digital mental health to impact those who are most vulnerable we must be vigilant when addressing these disparities. Ensuring digital data collected for mental health purposes is not repurposed and used for 
surveillance or sold for profits/marketing is critical, as any lack of trust or transparency in such a system will erode meaningful use. A focus on equity and ethics will ensure digital health truly increases access to care [40].

The COVID-19 crisis and global pandemic may be the defining moment for digital mental health, but what that definition will be remains unknown. Ensuring the right use of telehealth and app tools today in this crisis and investment in people and training to support them tomorrow during the potential mental health fallout of the current crisis as well as readiness for tomorrow can cement the future of digital mental health as simply mental health. Bending the curve in the right direction (Figure 1) will require funding, research, policy changes, training, and equity, but these investments will continue to yield higher returns at every step.

\section{Acknowledgments}

JT is supported by a career development award from the NIMH (1K23MH116130-03). JF is supported by a University of Manchester Presidential Fellowship P123958.

\section{Conflicts of Interest}

JT reports unrelated research support from Otsuka. The views and opinions expressed in this article are those of the authors and do not reflect those of any employer, granting agency, hospital, health care system, government, or official policy.

\section{References}

1. Wind T, Rijkeboer M, Andersson G, Riper H. The COVID-19 pandemic: The 'black swan' for mental health care and a turning point for e-health. Internet Interventions 2020 Mar:100317 Accepted manuscript. Published online March 19, 2020 [FREE Full text] [doi: 10.1016/j.invent.2020.100317]

2. Ben-Zeev D, Buck B, Kopelovich S, Meller S. A technology-assisted life of recovery from psychosis. NPJ Schizophr 2019 Sep 18;5(1):15 [FREE Full text] [doi: 10.1038/s41537-019-0083-y] [Medline: 31534139]

3. Lipschitz J, Hogan TP, Bauer MS, Mohr DC. Closing the Research-To-Practice Gap in Digital Psychiatry. J Clin Psychiatry 2019 May 14;80(3). [doi: 10.4088/jcp.18com12659]

4. Wong QJ, Werner-Seidler A, Torok M, van Spijker B, Calear AL, Christensen H. Service Use History of Individuals Enrolling in a Web-Based Suicidal Ideation Treatment Trial: Analysis of Baseline Data. JMIR Ment Health 2019 Apr 02;6(4):e11521 [FREE Full text] [doi: 10.2196/11521] [Medline: $\underline{30938686}$ ]

5. Matcham F, Barattieri di San Pietro C, Bulgari V, de Girolamo G, Dobson R, Eriksson H, RADAR-CNS consortium. Remote assessment of disease and relapse in major depressive disorder (RADAR-MDD): a multi-centre prospective cohort study protocol. BMC Psychiatry 2019 Feb 18;19(1):72 [FREE Full text] [doi: 10.1186/s12888-019-2049-z] [Medline: 30777041]

6. Graham SA, Lee EE, Jeste DV, Van Patten R, Twamley EW, Nebeker C, et al. Artificial intelligence approaches to predicting and detecting cognitive decline in older adults: A conceptual review. Psychiatry Res 2020 Feb;284:112732. [doi: 10.1016/j.psychres.2019.112732] [Medline: 31978628]

7. Sander L, Gerhardinger K, Bailey E, Robinson J, Lin J, Cuijpers P, et al. Suicide risk management in research on internet-based interventions for depression: A synthesis of the current state and recommendations for future research. J Affect Disord 2020 Feb 15;263:676-683. [doi: 10.1016/j.jad.2019.11.045] [Medline: 31757622]

8. Becker D, Bremer V, Funk B, Hoogendoorn M, Rocha A, Riper H. Evaluation of a temporal causal model for predicting the mood of clients in an online therapy. Evid Based Ment Health 2020 Feb 11;23(1):27-33. [doi: 10.1136/ebmental-2019-300135] [Medline: 32046990]

9. Muke SS, Shrivastava RD, Mitchell L, Khan A, Murhar V, Tugnawat D, et al. Acceptability and feasibility of digital technology for training community health workers to deliver brief psychological treatment for depression in rural India. Asian J Psychiatr 2019 Oct;45:99-106. [doi: 10.1016/j.ajp.2019.09.006] [Medline: $\underline{31557716]}$

10. CMS.gov. 2020 Mar 17. Medicare telemedicine health care provider fact sheet URL: https://www.cms.gov/newsroom/ fact-sheets/medicare-telemedicine-health-care-provider-fact-sheet [accessed 2020-03-24]

11. Yellowlees P, Shore JH. Telepsychiatry and Health Technologies: A Guide for Mental Health Professionals. Washington, DC: American Psychiatric Assoc Pub; 2018.

12. Gilbody S, Littlewood E, Hewitt C, Brierley G, Tharmanathan P, Araya R, et al. Computerised cognitive behaviour therapy (cCBT) as treatment for depression in primary care (REEACT trial): large scale pragmatic randomised controlled trial. BMJ 2015 Nov 11:h5627. [doi: 10.1136/bmj.h5627]

13. Torous J, Lipschitz J, Ng M, Firth J. Dropout rates in clinical trials of smartphone apps for depressive symptoms: A systematic review and meta-analysis. J Affect Disord 2020 Feb 15;263:413-419. [doi: 10.1016/j.jad.2019.11.167] [Medline: $\underline{31969272]}$

14. Mohr DC, Weingardt KR, Reddy M, Schueller SM. Three Problems With Current Digital Mental Health Research ... and Three Things We Can Do About Them. Psychiatr Serv 2017 May 01;68(5):427-429 [FREE Full text] [doi: 10.1176/appi.ps.201600541] [Medline: 28412890] 
15. Lattie EG, Nicholas J, Knapp AA, Skerl JJ, Kaiser SM, Mohr DC. Opportunities for and Tensions Surrounding the Use of Technology-Enabled Mental Health Services in Community Mental Health Care. Adm Policy Ment Health 2020 Jan;47(1):138-149. [doi: 10.1007/s10488-019-00979-2] [Medline: 31535235]

16. Birckhead B, Khalil C, Liu X, Conovitz S, Rizzo A, Danovitch I, et al. Recommendations for Methodology of Virtual Reality Clinical Trials in Health Care by an International Working Group: Iterative Study. JMIR Ment Health 2019 Jan 31;6(1):e11973 [FREE Full text] [doi: 10.2196/11973] [Medline: 30702436]

17. Milne-Ives M, Lam C, De Cock C, Van Velthoven MH, Meinert E. Mobile Apps for Health Behavior Change in Physical Activity, Diet, Drug and Alcohol Use, and Mental Health: Systematic Review. JMIR Mhealth Uhealth 2020 Mar 18;8(3):e17046 [FREE Full text] [doi: 10.2196/17046] [Medline: $\underline{\text { 32186518] }}$

18. Weisel KK, Fuhrmann LM, Berking M, Baumeister H, Cuijpers P, Ebert DD. Standalone smartphone apps for mental health-a systematic review and meta-analysis. NPJ Digit Med 2019 Dec 2;2(1):118 [FREE Full text] [doi:

10.1038/s41746-019-0188-8] [Medline: 31815193]

19. Torous J, Haim A. Dichotomies in the Development and Implementation of Digital Mental Health Tools. Psychiatr Serv 2018 Dec 01;69(12):1204-1206 [FREE Full text] [doi: 10.1176/appi.ps.201800193] [Medline: $\underline{30256182}$ ]

20. Firth J, Torous J, Nicholas J, Carney R, Pratap A, Rosenbaum S, et al. The efficacy of smartphone-based mental health interventions for depressive symptoms: a meta-analysis of randomized controlled trials. World Psychiatry 2017 Oct 21;16(3):287-298 [FREE Full text] [doi: 10.1002/wps.20472] [Medline: 28941113]

21. Wisniewski H, Henson P, Torous J. Using a Smartphone App to Identify Clinically Relevant Behavior Trends Symptom Report, Cognition Scores, and Exercise Levels: A Case Series. Front Psychiatry 2019 Sep 23;10:652 [FREE Full text] [doi: 10.3389/fpsyt.2019.00652] [Medline: $\underline{31607960}$ ]

22. Torous J, Wisniewski H, Bird B, Carpenter E, David G, Elejalde E, et al. Creating a Digital Health Smartphone App and Digital Phenotyping Platform for Mental Health and Diverse Healthcare Needs: an Interdisciplinary and Collaborative Approach. J Technol Behav Sci 2019 Apr 27;4(2):73-85. [doi: 10.1007/s41347-019-00095-w]

23. Larsen ME, Huckvale K, Nicholas J, Torous J, Birrell L, Li E, et al. Using science to sell apps: Evaluation of mental health app store quality claims. NPJ Digit Med 2019 Mar 22;2(1):18 [FREE Full text] [doi: 10.1038/s41746-019-0093-1] [Medline: $\underline{31304366]}$

24. Baumel A, Muench F, Edan S, Kane JM. Objective User Engagement With Mental Health Apps: Systematic Search and Panel-Based Usage Analysis. J Med Internet Res 2019 Sep 25;21(9):e14567 [FREE Full text] [doi: 10.2196/14567] [Medline: $\underline{31573916]}$

25. Torous J, Firth J, Huckvale K, Larsen ME, Cosco TD, Carney R, et al. The Emerging Imperative for a Consensus Approach Toward the Rating and Clinical Recommendation of Mental Health Apps. The Journal of Nervous and Mental Disease 2018;206(8):662-666. [doi: 10.1097/nmd.0000000000000864]

26. Carlo AD, Hosseini Ghomi R, Renn BN, Areán PA. By the numbers: ratings and utilization of behavioral health mobile applications. NPJ Digit Med 2019 Jun 17;2(1):54 [FREE Full text] [doi: 10.1038/s41746-019-0129-6] [Medline: 31304400]

27. Henson P, David G, Albright K, Torous J. Deriving a practical framework for the evaluation of health apps. The Lancet Digital Health 2019 Jun;1(2):e52-e54. [doi: 10.1016/s2589-7500(19)30013-5]

28. Firth J, Siddiqi N, Koyanagi A, Siskind D, Rosenbaum S, Galletly C, et al. The Lancet Psychiatry Commission: a blueprint for protecting physical health in people with mental illness. The Lancet Psychiatry 2019 Aug;6(8):675-712. [doi: $10.1016 / \mathrm{S} 2215-0366(19) 30132-4]$

29. Smith KJ, Victor C. Typologies of loneliness, living alone and social isolation, and their associations with physical and mental health. Ageing and Society 2018 Apr 10;39(8):1709-1730. [doi: 10.1017/s0144686x18000132]

30. Vancampfort D, Stubbs B, Firth J, Van Damme T, Koyanagi A. Sedentary behavior and depressive symptoms among 67,077 adolescents aged 12-15 years from 30 low- and middle-income countries. Int J Behav Nutr Phys Act 2018 Aug 08;15(1):73 [FREE Full text] [doi: 10.1186/s12966-018-0708-y] [Medline: 30089487]

31. Orben A, Przybylski AK. The association between adolescent well-being and digital technology use. Nat Hum Behav 2019 Feb 14;3(2):173-182. [doi: 10.1038/s41562-018-0506-1] [Medline: 30944443]

32. Lunde P, Nilsson BB, Bergland A, Kværner KJ, Bye A. The Effectiveness of Smartphone Apps for Lifestyle Improvement in Noncommunicable Diseases: Systematic Review and Meta-Analyses. J Med Internet Res 2018 May 04;20(5):e162 [FREE Full text] [doi: 10.2196/jmir.9751] [Medline: 29728346]

33. Frasquilho D, Matos MG, Salonna F, Guerreiro D, Storti CC, Gaspar T, et al. Mental health outcomes in times of economic recession: a systematic literature review. BMC Public Health 2016 Feb 03;16(1):115 [FREE Full text] [doi: 10.1186/s12889-016-2720-y] [Medline: 26847554]

34. Hilty D, Chan S, Torous J, Luo J, Boland R. A Framework for Competencies for the Use of Mobile Technologies in Psychiatry and Medicine: Scoping Review. JMIR Mhealth Uhealth 2020 Feb 21;8(2):e12229 [FREE Full text] [doi: 10.2196/12229] [Medline: 32130153]

35. Hilty DM, Maheu MM, Drude KP, Hertlein KM. The Need to Implement and Evaluate Telehealth Competency Frameworks to Ensure Quality Care across Behavioral Health Professions. Acad Psychiatry 2018 Dec 13;42(6):818-824. [doi: 10.1007/s40596-018-0992-5] [Medline: 30426453] 
36. Sunderji N, Crawford A, Jovanovic M. Telepsychiatry in graduate medical education: a narrative review. Acad Psychiatry 2015 Feb 26;39(1):55-62. [doi: 10.1007/s40596-014-0176-x] [Medline: 25155424]

37. Waseh S, Dicker AP. Telemedicine Training in Undergraduate Medical Education: Mixed-Methods Review. JMIR Med Educ 2019 Apr 08;5(1):e12515 [FREE Full text] [doi: 10.2196/12515] [Medline: 30958269]

38. Wisniewski H, Torous J. Digital navigators to implement smartphone and digital tools in care. Acta Psychiatr Scand 2020 Jan 13. [doi: 10.1111/acps.13149] [Medline: $\underline{31930477]}$

39. Hoffman L, Wisniewski H, Hays R, Henson P, Vaidyam A, Hendel V, et al. Digital Opportunities for Outcomes in Recovery Services (DOORS): A Pragmatic Hands-On Group Approach Toward Increasing Digital Health and Smartphone Competencies, Autonomy, Relatedness, and Alliance for Those With Serious Mental Illness. J Psychiatr Pract 2020 Mar;26(2):80-88. [doi: 10.1097/PRA.0000000000000450] [Medline: 32134881]

40. Nebeker C, Bartlett Ellis RJ, Torous J. Development of a decision-making checklist tool to support technology selection in digital health research. Transl Behav Med 2019 May 23:23. [doi: 10.1093/tbm/ibz074] [Medline: 31120511]

\section{Abbreviations \\ DOORS: Digital Opportunities for Outcomes in Recovery Services}

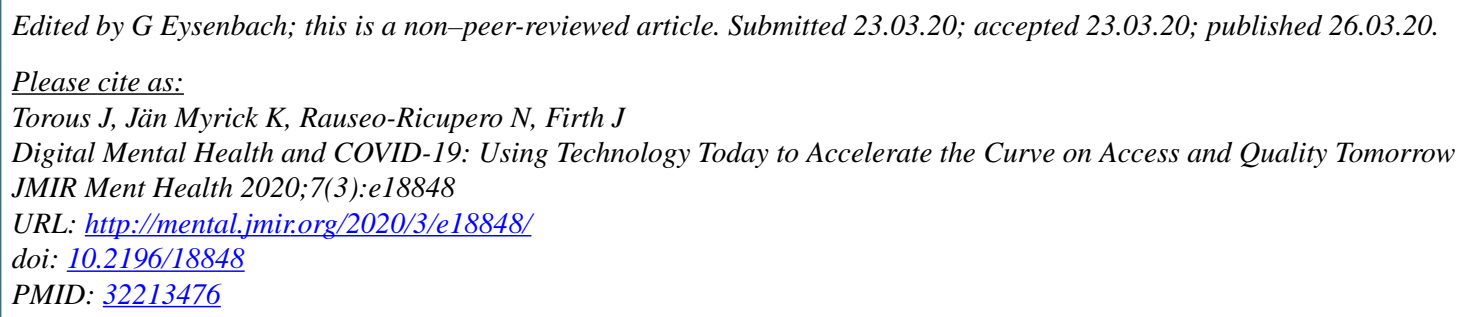

CJohn Torous, Keris Jän Myrick, Natali Rauseo-Ricupero, Joseph Firth. Originally published in JMIR Mental Health (http://mental.jmir.org), 26.03.2020. This is an open-access article distributed under the terms of the Creative Commons Attribution License (https://creativecommons.org/licenses/by/4.0/), which permits unrestricted use, distribution, and reproduction in any medium, provided the original work, first published in JMIR Mental Health, is properly cited. The complete bibliographic information, a link to the original publication on http://mental.jmir.org/, as well as this copyright and license information must be included. 